\title{
Molecular study to detect the Eimeria species in sheep in Al-Diwaniyah province, Iraq
}

\author{
N.M. Majeed ${ }^{1}$, N.N. A'aiz ${ }^{2}$ and A.J. Niemah ${ }^{3}$ \\ ${ }^{1,2}$ Department of Microbiology and Parasitology, ${ }^{3}$ Department of Zoonotic diseases, College of Veterinary Medicine, \\ University of Al-Qadisiyah, Iraq \\ Email: ${ }^{1}$ noora.mohammed823@gmail.com ${ }^{2}$ noaman.aaiz@qu.edu.iq, ${ }^{3}$ ahmed.neamah@qu.edu.iq
}

(Received September 6, 2019; Accepted September 30, 2019; Available online July 23, 2020)

\begin{abstract}
Sheep eimriosis is one of the most important and common disease which infects sheep in all ages but it is more effective in lambs. The diarrhea with or without blood is the main signs of infection. Eimeria protozoan required single host to complete its life cycle which pass in different stages including schizogony, gametogony and sporogony. The study was designed for detection of sheep Eimeria species through the molecular method. This study was conducted in Al-Diwanyah province during the winter months of 2019. In which 200 sheep fecal samples were collected and examined traditionally to investigate the Eimeria oocytsts. Ninety-seven samples of highly intensity infection with Eimeria oocysts were selected to subject for DNA extraction process. The extracted DNAs were tested through amplification of internal transcribed spacer 1 (ITS-1) gene by conventional PCR, and then phylogenetic analysis was made to diagnose the sheep Eimeria species. All samples that examined microscopically were showed positive results of infections with Eimeria protozoan. Out of 97 molecularly examined samples, forty-five (46.39\%) were given positive result in conventional PCR technique, where Eimeria spp. detected through succeeded amplification of internal transcribed spacer 1 (ITS-1) gene. Then phylogenetic analysis referred to that there are five species of Eimeria confirmed in sheep in Al-Diwanyah province including $6(33.33 \%)$ samples diagnosed as E. ahsata, $4(22.22 \%)$ samples E. weybridgensis, $3(16.66 \%)$ samples E. ovinoidalis, $3(16.66 \%)$ samples E. bovis and $2(11.11 \%)$ samples $E$. auburnensis. So, the Eimeria protozoan appears as an endemic parasite and can infect sheep with different species in study area. The sheep can infect with both specific and nonspecific species.
\end{abstract}

Keywords: Eimeria, Molecular, Sheep, Al-Diwaniyah

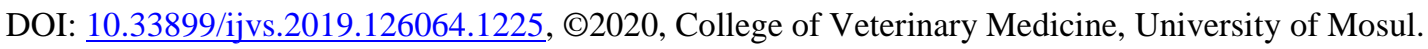

This is an open access article under the CC BY 4.0 license (http://creativecommons.org/licenses/by/4.0/).

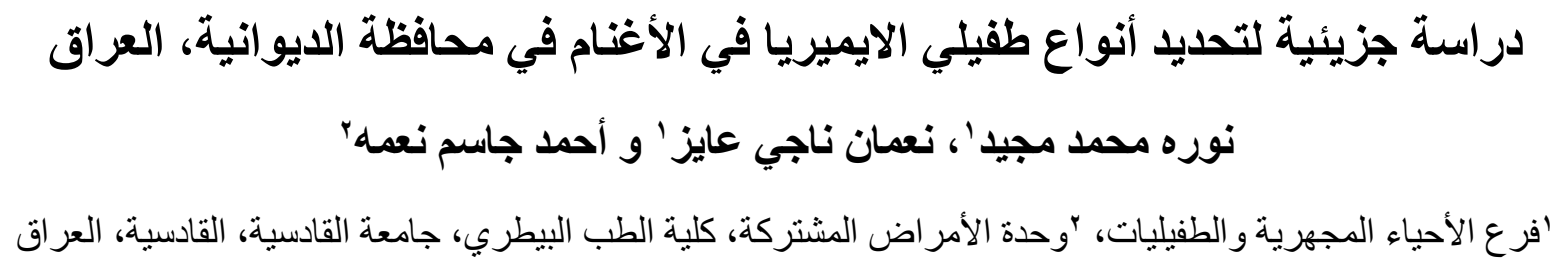

الخلاصة

تُعد كوكسيديا الأغنام من أكثر الأمر اض شيو اضعًا حيث تصيب الأغنام في جميع الأعمار ولكنها أكثر تأثثير اً في الحملان. يعتبر الإسهال

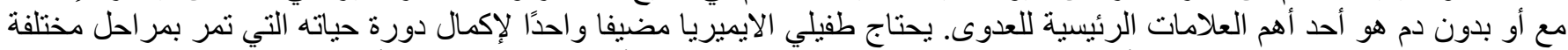

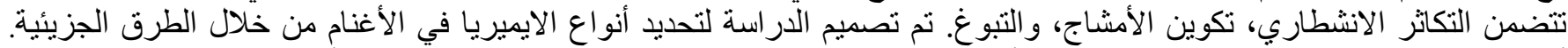

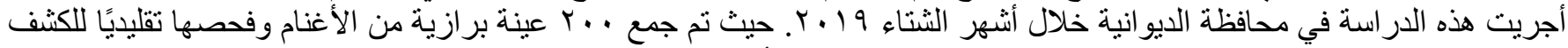

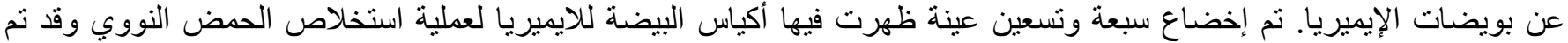
اختبار الحمض النووي المستخلص من خلال تضخيم الجين الفاصل الداخلي ا بواسطة تفاعل سلسلة إنزيم البولمر التقليدي، ثم تم إجراء 


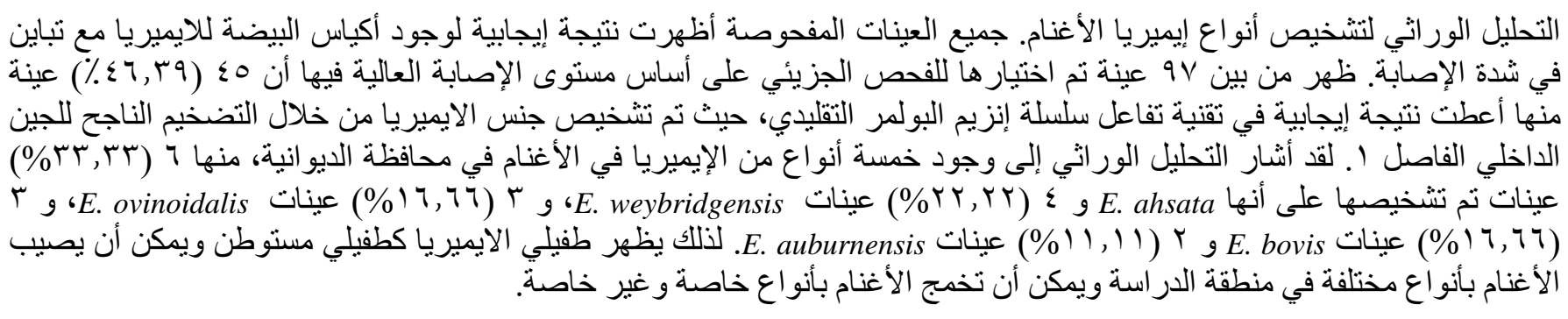

\section{Introduction}

Coccidiosis is an importance economic disease in all animals which can be significant problem in the young's members (1). Coccidiosis in sheep can be a serious disease that causes severe diarrhea, emaciation and sometimes death (2). The disease is more serious when sheep are reared in a closed breeding system, in particularly; lambs kept in overcrowded barns or on irrigated pastures during winter months (3).

The parasite has two phases of life cycle, endogenous phase in which the parasite undergoes numerous divisions in the intestinal cells, Where the ingested sporulated oocysts release sporozoites in intestinal lumen (excystation); and the exogenous phase which takes place outside of body in the environment under certain conditions (4).

Ingestion of contaminated food and water are the main source of infection and the symptoms of the disease begin with diarrhea, sometimes containing mucus or/ and blood, loss appetite, weight loss, anemia, fatigue, wool breaking and finally death of the animal (5).

The morbidity of the disease may be reach $10-40 \%$ and the mortality about $10 \%(5,6)$ Eimeria highly hosts specific and the disease is usually caused by sporulated oocysts $(7,8)$.

Different species of Eimeria parasitize the sheep intestine and mixed infections with a number of Eimeria spp. are common in natural infections (9).

Different sheep Eimeria species were recorded worldwide including E. ahsata, E. bakuensis, E. parva, E. pallida, E. crandallis, E. weybridgensis, E. ovina, E. ovinoidalis, E. granulosa, E. intricata, E. faurei and E. marsica (2). Among these species only E. ovinoidalis and E. crandallis are appeared to be pathogenic and lead to the most severe infections (10).

Differentiation among these different species is depending mainly upon shape and measurements of oocysts, infection site and sporulation time, but may be unreliable methods due to the large overlapping in size and shape of these different species $(11,12)$.

Many methods were used in the diagnosis of Eimeria depending upon fecal examination, serological and molecular (13).
Sensitive and specific fecal examination results can get by use of molecular techniques (14). PCR based on amplification of DNA that has been used for the diagnosis of Eimeria in different hosts and have proved to give accurate results in different used samples (15).

As sheep are regarded as the good source of protein for the study area population, therefore the needing to increase the protein sources requires understanding any disease aliment such as coccidian infection which can limit the production of small stocks. So, given that most traditional diagnostic examinations have a significant error rate, we consider studying the diagnosis of Eimeria species based on molecular methods.

\section{Materials and methods}

Two hundred sheep fecal samples 5-10 gram were collected directly from animals' rectum and put in clean plastic labeled containers, then transported with ice bags to a Parasitology laboratory in the College of Veterinary Medicine, University of Al-Qadisiya. These samples were getting from different regions of Al-Diwaniyah province during the winter months of 2019.

All samples were examined by flotation method (16), to investigate the Eimeria oocysts. DNA extraction was done for certain positive samples selected based on the density of oocysts existing using fecal DNA extraction kit (Favorgen Biotech Corp ${ }^{\circledR}$, Bioneer, Korea) according to manufacturer directives. The purity of extracted DNA was measured by using a Nanodrop spectrophotometer (THERMO. USA), at $260 / 280 \mathrm{~nm}$ absorbance, then stored at $-20{ }^{\circ} \mathrm{C}$ till used.

Conventional PCR technique was performed to amplification the extracted DNA at 18SrRNA (ITS-1) gene according to a method described by (15), where Eimeria common primers were used (IDT, Canada).

The up-and downstream sequences in internal transcribed spacer 1 (ITS-1) region were: F: 5'- GCA AAA GTC GTA ACA CGG TTT CCG -3', R: 5'- CTG CAA TTC ACA ATG CGT ATC GC-3' with expected product sizes of 348-546 bp. PCR construction was prepared by using (AccuPower PCR PreMix Kit), whereby for $50 \mu \mathrm{l}$ volume of PreMix Kit tube (Taq DNA polymerase, dNTPs, Tris. $\mathrm{HCl}$ pH: 9.0, $\mathrm{KCl}, \mathrm{MgCl}_{2}$, stabilizer, and tracking dye) $5 \mu \mathrm{l}$ of extracted DNA and $1.5 \mu 1(10 \mathrm{pmol})$ of both forward 
and reverse primers were added, then the volume completed with nuclease free distilled water.

Reaction conditions set as an initial denaturation at $94^{\circ} \mathrm{C}$ for $30 \mathrm{sec}$ followed by $35 \mathrm{cycles}$ at $94^{\circ} \mathrm{C}$ for $10 \mathrm{sec}, 55^{\circ} \mathrm{C}$ for $45 \mathrm{sec}$, and $72^{\circ} \mathrm{C}$ for $20 \mathrm{sec}$ with final extension at $72^{\circ} \mathrm{C}$ for 2 min using PCR thermocycler (Thechne/ USA). The PCR products were analyzed by $1.5 \%$ agarose gel electrophoresis.

To detect the Eimeria species, PCR positive samples were subjected to DNA sequencing (Bioneer / Korea) by AB DNA sequencing system. The Phylogenetic analysis was performed based on NCBI-Blast Alignment identification and Unweighted Pair Group method with Arithmetic Mean (UPGMA tree) in (MEGA 6.0 version).

\section{Results}

All samples $100 \%$ that examined microscopically showed positive results for Eimeria oocysts in different intensity of infections (Figure 1). Ninety-seven samples were selected according to their heavy infection for DNA extraction. Where $4546.39 \%$ extracted DNA showed positive results when succeeded amplification of internal transcribed spacer 1 (ITS-1) gene through conventional PCR technique to produce $348-546$ bp product (Figure 2).

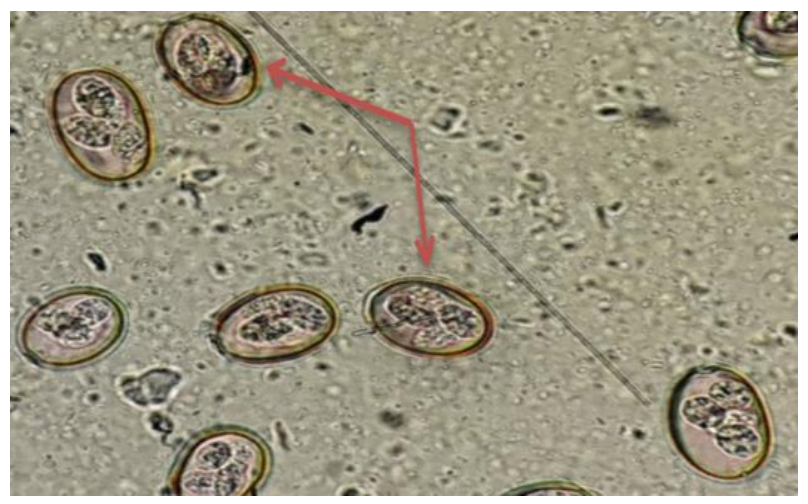

Figure 1: Sheep Eimeria oocysts.

For getting perfect sequencing results, 18 positive samples of more specific PCR products were subjected to DNA sequencing to detect sheep Eimeria species. Where the results revealed that $6(33.33 \%)$ samples diagnosed as E. ahsata (accession no. MN269978, MN269980, MN306558, MN269981, MN269982, MN269984), 4 $(22.22 \%)$ E. weybridgensis (MN306559, MN306560, MN306561, MN306563), $3(16.66 \%)$ E. ovinoidalis (MN306556, MN306565, MN306566) and $3(16.66 \%) E$. bovis (MN306557, MN306562, MN306564) and 2 (11.11\%) E. auburnensis (MN269979, MN269983) (Table 1; Figure 3).

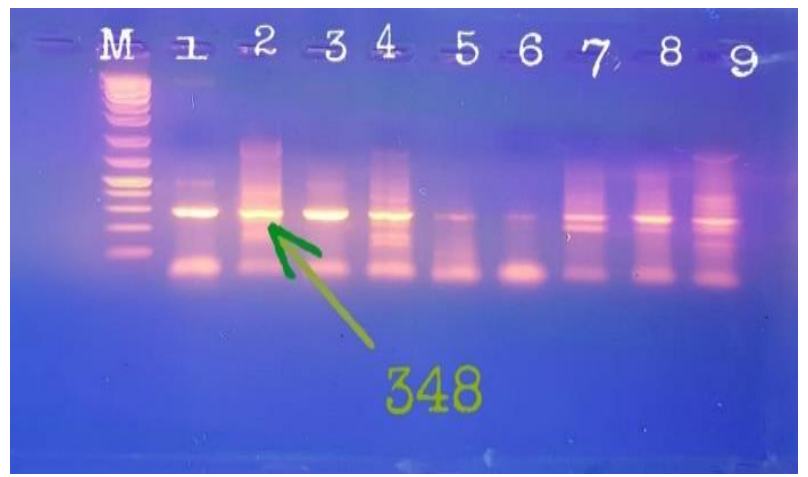

Figure 2: PCR product of agarose gel electrophoresis of Eimeria ITS-1 gene (348- 546 bp), where; M: 1000bp DNA ladder; Lanes 1-9 Positive samples.

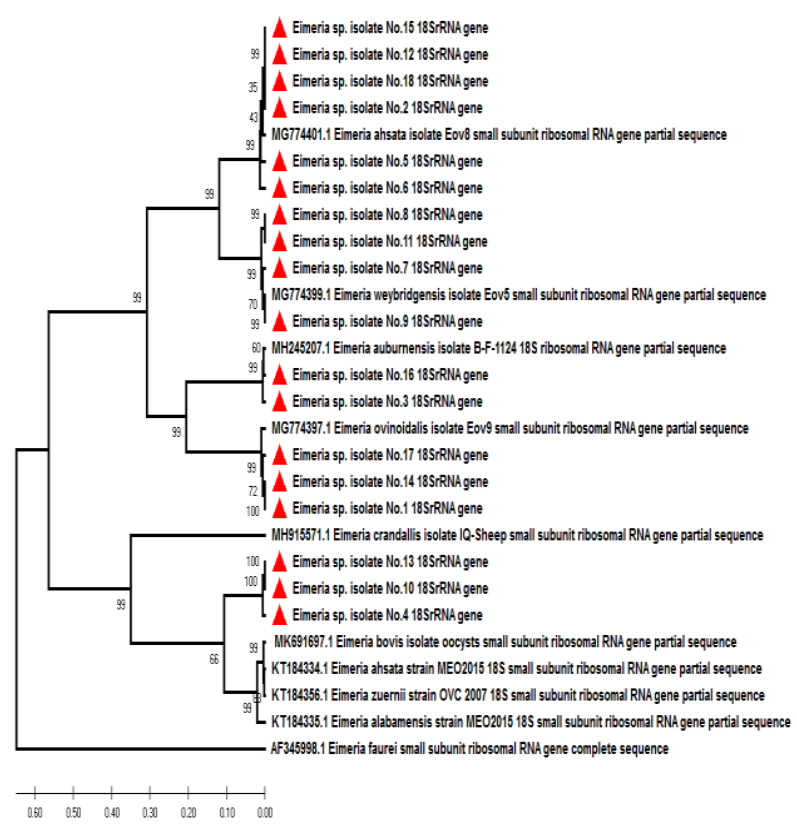

Figure 2: Phylogenetic tree analysis based on 18S rRNA gene partial sequence in local Eimera spp. isolates that used for genetic identification. The phylogenetic tree was constructed using Unweighted Pair Group method with Arithmetic Mean (UPGMA tree) in (MEGA 6.0 version) at total genetic changes $(0.10-0.60 \%)$.

\section{Discussion}

Eimeria protozoan is a principal etiologic agent for coccidiosis in livestock, where the sickness causes economic loss in sheep as a result of the drop in milk and meat production, paleness, and the increment of the prospect to induce mortality (17). 
Table1: NCBI-Blast homology sequence identity (\%) among local Eimeria spp. and NCBI-BLAST submitted Eimeria spp. isolates

\begin{tabular}{lcccc}
\hline \multirow{2}{*}{ Eimeria spp isolates No. } & \multicolumn{4}{c}{ Homology sequence identify } \\
\cline { 2 - 5 } & Genbank Accession number & NCBI - Blast isolates & Gene bank AN. & Identify \% \\
\hline 1 & MN306556 & E. ovinoidalis & MG774397.1 & $98.19 \%$ \\
2 & MN269978 & E. ahsata & MG774401.1 & $98.84 \%$ \\
3 & MN269979 & E. auburnensis & MH245207.1 & $99.28 \%$ \\
4 & MN306557 & E. bovis & MK691697.1 & $99.75 \%$ \\
5 & MN269980 & E. ahsata & MG774401.1 & $98.84 \%$ \\
6 & MN306558 & E. ahsata & MG774401.1 & $98.27 \%$ \\
7 & MN306559 & E. weybrigensis & MG774399.1 & $98.84 \%$ \\
8 & MN306560 & E. weybrigensis. & MG774399.1 & $98.52 \%$ \\
9 & MN306561 & E. weybrigensis & MG774399.1 & $100.00 \%$ \\
10 & MN306562 & E. bovis & MK691697.1 & $99.25 \%$ \\
11 & MN306563 & E. weybrigensis & MG774399.1 & $98.52 \%$ \\
12 & MN269981 & E. ahsata & MG774401.1 & $98.84 \%$ \\
13 & MN306564 & E. bovis & MK691697.1 & $99.24 \%$ \\
14 & MN306565 & E. ovinoidalis & MG774397.1 & $98.17 \%$ \\
15 & MN269982 & E. ahsata & MG774401.1 & $98.84 \%$ \\
16 & MN269983 & E. auburnensis & MH245207.1 & $99.28 \%$ \\
17 & MN306566 & E. ovinoidalis & MG774397.1 & $97.79 \%$ \\
18 & MN269984 & E. ahsata & MG774401.1 & $98.84 \%$ \\
\hline
\end{tabular}

Molecular and phylogenetic studies for Eimeria species identification in ruminants are few compared with studies conducted on avian. The ITS1- rRNA genes has been showed to an effective target for some Eimeria species phylogenetic analysis $(15,18)$.

The results of the current study showed that all $100 \%$ microscopically examined samples have infection with different Eimeria spp. This result higher as compared with the results of studies were performed in India $70.44 \%$ and Iraq $72 \%$ by Om et al. (19) and Kareem and Yücel (20) respectively. These differences in outcomes may be due to differences in environmental, breeding and health care conditions.

Molecularly the results recorded five different species of Eimeria in sheep that which E. ahsata $33.33 \% E$. weybridgensis $22.22 \%$, E. ovinoidalis $16.66 \%$, E. bovis $16.66 \%$ and E. auburnensis $11.11 \%$, where the first three species are a specific for sheep, while the two later a specific for cattle. These results are agreed with the result of Platzer et al. (21) who recorded three species included $E$. ovinoidalis, E. weybridgensis and E. ahsata in Austria, Hashemni et al. (22) who recorded E. ahsata in Western Iran and Kara (23) who confirmed E. ovinoidalis in Turkey.

Most Iraqi previous studies depend upon classical method for detection of sheep Eimeria species $(20,24)$, except the study carried by Al-Saadoon (25) in Wasit who fixed 10 Eimeria species (E. ahsata, E. parva, E. pallida, E. bakuensis, E. ovinoidalis, E. crandallis, E. faurei, E. Intricate, E. weybridgensis, E. granulosa) by both classical and molecular methods recorded 11 species of Eimeria (E. bakuensis, E. weybridgensis, E. marsica, E. ovinoidalis, E. ahsata, E. parva, E. pallida, E. crandallis, E. faurei, E. intricata and E. granulosa) in Sulaimaniya, also in other study.

In this study two cattle species (E. bovis and $E$. auburnensis) were detected in sheep. These species were observed in previous studies in their specific host, where Ibrajim et al. (26) recorded E. bovis $25.84 \%$ and $E$. auburnensis 7.78\%, in Saudi Arabia in Subclinical bovine coccidiosis, also Bangoura et al. (27) showed E. bovis was more effective and highly pathogenic.

The appearing of these two cattle Eimeria species may be attribute to the common grazing in most fields between sheep and cattle that may lead to some hosts being infected with non-pathogenic or pathogenic Eimeria spp. of other host. In other hand the E. auburnensis is recorded for the first time in Iraq, at both cows or sheep, where previous studies have not indicated its recordation $(20,24,25)$.

The typical diagnosis of pathogens is important in understanding the biology and life cycle of them. Therefore, traditional methods of diagnosing coccidiosis do not achieve accurate diagnosis because of the significant overlap in the properties of different species (12).

\section{Conclusions}

The sheep eimeriosis is an endemic disease in AlDiwaniyah province and there are different Eimeria species can infect sheep in the study area. The molecular techniques are an accurate method in detection of Eimeria 
species, in addition to that sheep can infect with nonspecific species (E. bovis, E. auburnensis).

\section{Acknowledgements}

We acknowledge all the efforts of the veterinarians and farmers at the Al-Diwaniyah city for kindly helping in collecting the fecal samples.

\section{Conflict of Interest}

The authors declare that there are no conflicts of interest regarding the publication of this manuscript.

\section{References}

1. Hasan H, Abed M. A study of Eimeria species in sheep in Mosul City. Iraq. J. of Vet. Sci. 2012;26(1): 45-53. Doi: 10.33899/ijvs.2012.46816

2. Chartier C, Paraud C. Coccidiosis due to Eimeria in sheep and goats, a review. Small Rumin Res. 2012;103(1):84-92. Doi: 10.1016/j.smallrumres.2011.10.022

3. Khodakaram-Tafti A, Hashemnia M, Razavi S. M., Sharifiyazdi H., and Nazifi S. Genetic characterization and phylogenetic analysis of Eimeria arloingi in Iranian native kids. Parasitol. Res. 2013;112(9):3187-3192. Doi: 10.1007/s00436-013-3494-0

4. Mohamaden W. I., Sallam N. H., and Abouelhassan E. M., Prevalence of Eimeria species among sheep and goats in Suez Governorate. Egypt, Int. J. Vet. Sci. Med. 2018;6(1):65-72. Doi: 10.1016/j.ijvsm.2018.02.004

5. Khodakaram-Tafti A., Hashemnia M., Razavi S. M., Sharifiyazdi H., and Nazifi S. Genetic characterization and phylogenetic analysis of Eimeria arloingi in Iranian native kids. Parasitol. Res.2013;112(9):3187-3192. Doi: 10.1016/j.trivac.2016.02.001

6. Chhabra, R. C.; Pandey, V. S. Coccidia of goats in Zimbabwe. Vet. Parasitol. 1991;39(3-4):199-205. Doi: 10.1016/0304-4017(91)90036$\mathrm{U}$

7. Foreyt, William J. Coccidiosis and cryptosporidiosis in sheep and goats. Veterinary Clinics of North America: Food Animal Practice. 1990;6(3):655-670. Doi:10.1016/S0749-0720(15)30838-0

8. Jolley W.R., Bardsley K.D.: Ruminant coccidiosis. Vet. Clin. Food Anim. 2006; 22:613-621. Doi: 10.1016/j.cvfa.2006.07.004

9. O'Callaghan MG, O’Donoghue PJ, Moore E. Coccidia in sheep in south Australia. Vet Parasitol. 1987;24(3-4):175-183. Doi: 10.1016/0304-4017(87)90038-0

10. Gregory MW, Catchpole J, Joyner LP and Parker BNJ. Observations on the epidemiology of coccidial infections in sheep under varying conditions of intensive husbandry including chemoprophylaxis with monensin. Parasitol. 1983;87(3):421-427. Doi: $10.1017 / \mathrm{s} 0031182000082949$

11. Tenter AM, Barta JR, Beveridge I, Duszynski, DW, Mehlhorn H, Morrison DA, Conrad PA. The conceptual basis for a new classification of the coccidia. Inter J Parasitol. 2002;32(5):595-616. Doi: $\underline{10.1016 / \mathrm{s} 0020-7519(02) 00021-8}$
12. Haug A, Thebo P, Mattsson JG. A simplified protocol for molecular identification of Eimeria species in field samples. Vet Parasitol. 2007;146(1-2):35-45. Doi: 10.1016/j.vetpar.2006.12.015

13. Woods, W. G., et al. Single-strand restriction fragment length polymorphism analysis of the second internal transcribed spacer (ribosomal DNA) for six species of Eimeria from chickens in Australia. International journal for parasitology. 2000;30(9): 10191023. Doi:10.1016/S0020-7519(00)00084-9

14. Sweeny JPA, Ryan UM, Robertson ID, Yang R, Bell K, Jacobson C. Longitudinal investigation of protozoan parasites in meat lamb farms in southern western Australia. Prev Vet Med. 2011;101(3-4):192-203. Doi: 10.1016/j.prevetmed.2011.05.016

15. Kawahara F, Zhang G, Mingala CN, Tamura Y, Koiwa M, Onuma M, Nunoya T. Genetic analysis and development of species-specific PCR assays based on ITS-1 region of rRNA in bovine Eimeria parasites. Vet Parasitol. 2010;174(1-2):49-57. Doi: 10.1016/j.vetpar.2010.08.001

16. Eckert, Joelle. Identification of Eimeria species and strains. Morphological characteristics of oocysts. Biotechnology: guidelines on techniques in coccidiosis research. 1995; (16602):103-119. Doi: hal.inrae.fr/hal-02851848

17. Kenyon F, Jackson F. Targeted flock/herd and individual ruminant treatment approaches. Vet Parasitol. 2012;186(1-2):10-17. Doi: 10.1016/j.vetpar.2011.11.041

18. Khodakaram TA, Hashemnia M, Razavi SM, Sharifiyazdi H, and Nazifi S. Genetic characterization and phylogenetic analysis of Eimeria arloingi in Iranian native kids. Parasitol Res. 2013;112(9):3187-3192. Doi: 10.1007/s00436-013-3494-0

19. Om H, Kumar S, Singh P. Prevalence of coccidia in Mathura region of Uttarpradesh. Vet World. 2010;3(11):503. Doi: 2b7b/9a04e303b51326a806f4df4e5e53a4d71ca4.pdf

20. Kareem SI, Yücel SY. Prevalence of Eimeria species in sheep in Sulaimaniya province, Iraq. J Entomol Zool Stud. 2015;3(4):317-322. Doi: entomoljournal.com/vol3Issue4/pdf/3-4-73.1.pdf

21. Platzer B, Prosl H, Cieslicki M, Joachim A. Epidemiology of Eimeria infections in an Austrian milking sheep flock and control with diclazuril. Vet Parasitol. 2005;129(1-2):1-9. Doi: 10.1016/j.vetpar.2004.11.031

22. Hashemnia M, Rezaei F, Chalechale A, Kakaei S and Gheichivand S. Prevalence and intensity of Eimeria infection in sheep in Western Iran. Inter J Livestock Res. 2014;4(1):107-112. Doi: 10.5455/ijlr.20140109084416

23. Kara M. The prevalence of coccidian species in sheep in Kars province of Turkey. Trop Anim Heal Product. 1999;31(3):161-165. Doi: 10.1023/A:1005186624978

24. Lillehoj HS. Role of T lymphocytes and cytokines in coccidiosis. Inter J Parasitol. 1998;28(7):1071-1081. Doi: 10.1016/s00207519(98)00075-7

25. Al-Saadoon $\mathrm{Z} \mathrm{M}$. Traditional and molecular study for prevalence of coccidiosis in sheep in Wasit, Iraq. Indian $J$ Nat Sci. 2018;8(49):14394-1440. Doi: ISSN: 0976-0997

26. Ibrahim MM, Soliman MF, Alghamdi AO. Subclinical bovine coccidiosis in Al-Baha Area, Saudi Arabia. Int J Vet Sci Res. 2015;1(1):23-28. Doi: /10.17352/ijvsr.000005

27. Bangoura B, Mundt HC, Schmäschke R, Westphal B, Daugschies A. Prevalence of Eimeria bovis and Eimeria zuernii in German cattle herds and factors influencing oocyst excretion. Parasitol Res. 2012;110(2):875-881. Doi: 10.1007/s00436-011-2409-1 